\title{
ELASTIC-PLASTIC RESPONSE CHARTS FOR NUCLEAR OVERPRESSURES
}

\author{
by \\ RECEIVED \\ L. K. Guice, S. A. Kiger \\ AUG 061984 \\ Structures Laboratory \\ J. D. HALTIWANGER \\ DEPARTMENT OF THE ARMY \\ Waterways Experiment Station, Corps of Engineers \\ PO Box 631 \\ Vicksburg, Mississippi 39180
}

\section{UNIVERSITY OF ILLINOIS \\ LIBRARY \\ AT URBANA-CHAMPAIGN \\ ENGINEERING}

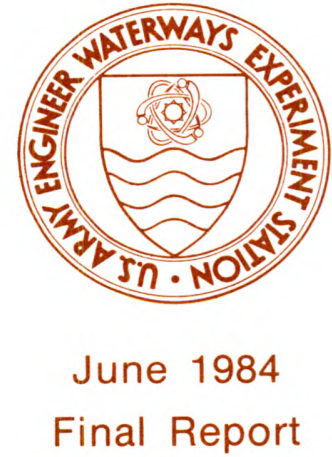

Approved For Public Release; Distribution Unlimited

Prepared for Defense Nuclear Agency Washington, DC 20305

and DEPARTMENT OF THE ARMY

US Army Corps of Engineers Washington, DC 20314

Under DNA Subtask Y99QAXSC, Work Unit 00080 and OCE R\&D Project 4A762710^T^n Task AO, Work Unit $C$ 